\title{
Post Parturient Behavioural Profiles in Primiparous and Multiparous Gir Cows
}

\author{
R.V. Vora $^{1}{ }^{*}$, N.B. Patel ${ }^{1}$, T.K.S. Rao ${ }^{1}$, R.N. Gelani ${ }^{2}$ and M.M. Goswami ${ }^{3}$ \\ ${ }^{1}$ Department of Livestock Production Management, Vanbandhu College of Veterinary Science \\ and A. H, Navsari Agricultural University, Navsari, Gujarat, India \\ ${ }^{2}$ Nandini Bhestan Farm, Bhestan, Surat, Gujarat, India \\ ${ }^{3}$ Department of Livestock Products Technology, College of Veterinary Science and A. H., \\ Guru Angad Dev Veterinary and Animal Science University, Ludhiana, Punjab, India.
}

*Corresponding author

\section{A B S T R A C T}

\section{Keywords \\ Parity, Primiparous, Multiparous, Post- partum behavior, Gir cow \\ Article Info \\ Accepted: \\ 20 November 2018 Available Online: \\ 10 December 2018}

The experiment was conducted to investigate the post-partum behavioral activities (up to 12 hour postpartum) of 6 multiparous and 6 primiparous Gir cows towards their calves using low light-intensity cameras and video recorder. To facilitate behavioural data recording at night the calving pen was illuminated with bulbs. As the animal was accustomed to the similar light during the night at the farm, such illumination during the experiment was not being likely to influence the behaviour of the animals. Gir cows were divided into 2 groups based on their parity, group-1 (primiparous cow) and group-2 (multiparous cow). Total resting time (min.) was significantly $(\mathrm{p}<0.01)$ higher in primiparous $(245.50 \pm 5.75)$ than multiparous $(218.33 \pm 4.94)$ Gir cows. Licking and grooming time (min.) was significantly $(\mathrm{p}<0.01)$ higher in multiparous $(130.17 \pm 6.88)$ than primiparous $(104.33 \pm 3.35)$ Gir cows. The result may be suggested that parity has significant effect over the post parturient behaviour of Gir cow.

\section{Introduction}

Gir is one of the best milch breed among indigenous cattle. As per $19^{\text {th }}$ Livestock census, total population of Gir cattle is 51.12 lakh which contributes $3.38 \%$ of total indigenous cattle population of the country. Gir is considered to be one of the most gentle breed among the Zebu breeds of cattle. The behavioral events during early post-partum period between mother and calf have an important bearing on the survival of neonatal calf and hence on the reproductive and productive performances of Gir cows. Primiparous cattle are generally calved for the first time at about 2-3 years of age as this maximizes economic benefit suggested by Hoffman and Funk (1992). Animals are not however physically mature at this age. Cows approaching their first calving are in a different metabolic state as compared to experienced by multiparous cows as they require nutrients for their own continued growth in addition to their developing calf. In 
present day farming, greater attention is paid to the understanding of animal behavior, in order to provide them with a greater welfare and thus obtain many benefits for the breeder as a global trend from maximizing to optimize livestock production which was suggested by Szarek et al., (2004). The aim of the study was to compare the behavior of primiparous and multiparous cows-mothers to their calves up to 12 hours post-partum. Edwards (1983) observed that multiparous has higher intensity of licking calves than primiparous and he also observed that 3 of 38 primiparous cows failed to lick their calf within first 6 hours after parturition but no multiparous cows failed to lick their calves. Several studies had shown that after parturition cows spent maximum time in Epimeletic behaviours like licking reported by Val-Laillet et al., (2004) whereas, least priority have been given to maintenance behaviours like eating and rumination behaviour during early post-partum period reported by Huzzey et al., (2005) and Pahl et al., (2014) respectively. Ansari (2011) reported that the mean expulsion time (min.) of placenta was primiparous (195.40) and multiparous (193.46) Deoni cattle, which was statistically non-significant between the parity. Licking of the calf after birth is important in strengthening the maternal bond between cow and calf. Several functions have been suggested for licking: removal of the fetal membranes; stimulation of activity and breathing, circulation, urination and defecation suggested by Metz and Metz (1986) and also reported that duration of licking decreased with time after calving.

\section{Materials and Methods}

\section{Location}

The experience was conducted from August to December, 2017 and carried out in the Gir breed of cattle at Bhestan farm, Bhestan, Surat.

\section{Experimental Design}

Observations were conducted in the parturition shed where cows about 3 weeks before the estimated day of parturition (highpregnancy) and at the time of calving and 7-10 days after, where held on pakka concrete floor with rubber mate. After parturition cows were allowed to contact with her calf for 24 hours period; after this period, calves were moved to calf shed. Experiment consisted of 6 primiparous and 6 multiparous cows. The lactation number of observed multiparous cows ranged from 2 to 4 .

All the animals in this experiment were raised under similar managemental practices. For observing the post-parturient behaviour of cow and calf, video recording was done with a low light-intensity high resolution camera. To facilitate behavioural data recording at night the calving pens was illuminated with bulbs. The intensity of lights was sufficient to note down all the behavioural activities. As the animal was accustomed to the similar light during the night at the farm, such illumination during the experiment was not being likely to influence the behaviour of the animals.

\section{Observations recorded}

Post-partum behavior such as resting hours, licking and grooming the calf, sniffing, nudging, butting, maternal rejection, expulsion of placenta, posture of dam during expulsion of placenta, licking of placenta without eating it, placentophagia, feeding time, rumination time, drinking time, urination and defecation frequency were examined.

\section{Statistical analysis}

The data on post parturition behavior studies were subjected to statistical analysis using SPSS (Statistical Package for Social Sciences, Version 20.0) software. Descriptive statistics 
specifying Mean \pm S.E., was calculated for each group. Independent sample t-test was used for two group comparisons. Percentages of data Post-parturient behaviour of Gir cows were also calculated by using SPSS software.

\section{Results and Discussion}

In cows, the natural behavior after the birth is a newborn's sniffing and licking. This characteristic behavior of cow is important in stimulating the calf activity and it has an effect on respiration, circulation, urination and defecation of the newborn reported by Metz and Metz (1986). Licking the calf dries its hair, reducing heat loss.

All of the monitored cows have shown interest to new born calf and none of them observed maternal rejection. Traits of cows behavior in post-partum period according to their parity is shown in table 1 and percentage of the different parameters are shown in table 2 .

During 12 hour post-partum overall time spent in resting behavior was $245.50 \pm 5.75$ and $218.33 \pm 4.94 \mathrm{~min}$. in primiparous and multiparous respectively (Table 1). Total resting time was significantly $(\mathrm{p}<0.01)$ higher in primiparous than the multiparous cows. It might be due to primiparous cow that calved for the first time which leads to pain and difficulty in parturition, which leads to standing up later and spent more time lying. Similar result was obtained by Kunowska and Rozanska (2009).

In 12 hour post-partum all cows spent time in licking and grooming with average duration of $104.33 \pm 3.35$ and $130.17 \pm 6.88 \mathrm{~min}$. in primiparous and multiparous cows respectively. Total licking and grooming time was significantly ( $\mathrm{p}<0.01)$ higher in multiparous cows than the primiparous cows (Table 1). In contrast to present study Metz (1984) suggested that the maternal behavior like licking and grooming time was independent on the lactation number of the animal or parity. Immediately after the delivery of the calf the cow stands up to lick her calf, licking was intense during the first hour after calving and then gradually decline in number of licks in the subsequent hours reported by Edwards and Broom(1982). In present study significant $(\mathrm{p}<0.05)$ difference was found between the primiparous and multiparous cows which is supported by Edwards and Broom (1982). They observed that multiparous cows show higher intensities of licking during the first hour after birth than do primiparous cows.

Sniffing was defined as proximity $(2 \mathrm{~cm})$ of nose of cow with body of calf with inhalation and exhalation of air through nose. The sniffing was shown by all of the cows. The onset of sniffing up to 12 hour post-partum was $27.17 \pm 2.44$ and $24.50 \pm 3.22$ minutes in primiparous and multiparous cows respectively and number of sniffing up to 12 hour post-partum was $8.67 \pm 0.88$ times and $13.83 \pm 1.70$ times in primiparous and multiparous cows respectively as depicted in table 1. Among 6 primiparous cows sniffing was observed in $5(83.3 \%)$ animal. But in multiparous cows all the $6(100 \%)$ animals showed sniffing behavior as depicted in table 2.

Nudging was defined as pressure applied by cow to calf with bridge of nose. The nudging was shown by all of the cows. The onset of nudging up to 12 hour post-partum was $41.92 \pm 1.97$ and $50.46 \pm 2.76$ minutes in primiparous and multiparous cows respectively; however number of nudging up to 12 hour post-partum was $8.50 \pm 0.56$ and $11.83 \pm 1.14$ times more in primiparous and multiparous cows respectively as observed in table 1 . All the animals in present experiment showed nudging behavior as summarized in table 2 . 
Table.1 Effect of parity on Post parturient behavior of Gir cows up to 12 hours

\begin{tabular}{|c|c|c|c|c|c|c|}
\hline Sr. no. & Parameters & $\mathbf{n}$ & $\begin{array}{c}\text { Primiparous } \\
\text { (Group - 1) }\end{array}$ & $\begin{array}{c}\text { Multiparous } \\
\text { (Group - 2) }\end{array}$ & t value & p value \\
\hline 1 & Total Resting time (min.) & 6 & $245.50 \pm 5.75$ & $218.33 \pm 4.94$ & 3.581 & 0.005 \\
\hline 2 & $\begin{array}{l}\text { Licking and grooming } \\
\text { (min.) }\end{array}$ & 6 & $104.33 \pm 3.35$ & $130.17 \pm 6.88$ & -3.376 & 0.007 \\
\hline 3 & Onset of sniffing (min.) & 6 & $27.17 \pm 2.44$ & $24.50 \pm 3.22$ & 0.660 & 0.524 \\
\hline 4 & No. of sniffing & 6 & $8.67 \pm 0.88$ & $13.83 \pm 1.70$ & -2.696 & 0.022 \\
\hline 5 & Nudging time (min.) & 6 & $41.92 \pm 1.97$ & $50.46 \pm 2.76$ & -2.516 & 0.031 \\
\hline 6 & No. of nudging & 6 & $8.50 \pm 0.56$ & $11.83 \pm 1.14$ & -2.626 & 0.025 \\
\hline 7 & Butting time (min.) & 6 & $91.27 \pm 5.60$ & $70.78 \pm 10.52$ & 1.720 & 0.116 \\
\hline 8 & No. of butting & 6 & $6.33 \pm 0.67$ & $8.67 \pm 0.71$ & -2.387 & 0.038 \\
\hline 9 & Total feeding time (min.) & 6 & $122.33 \pm 4.94$ & $109.83 \pm 6.78$ & 1.490 & 0.167 \\
\hline 10 & $\begin{array}{l}\text { Total rumination time } \\
\text { (min.) }\end{array}$ & 6 & $70.17 \pm 3.35$ & $58.50 \pm 4.81$ & 1.989 & 0.075 \\
\hline 11 & $\begin{array}{c}\text { Total drinking } \\
\text { time(min.) }\end{array}$ & 6 & $4.87 \pm 0.40$ & $4.89 \pm 0.46$ & 0.016 & 0.987 \\
\hline 12 & Urination no. & 6 & $2.33 \pm 0.21$ & $2.50 \pm 0.22$ & -0.542 & 0.599 \\
\hline 13 & Defecation no. & 6 & $3.00 \pm 0.26$ & $3.17 \pm 0.31$ & -0.415 & 0.687 \\
\hline
\end{tabular}

Table.2 Post parturient behavior percentage of Gir cows up to 12 hours

\begin{tabular}{|c|c|c|c|}
\hline Behavior & Incidence & $\begin{array}{c}\text { Primiparous No. } \\
\text { (Percentage) }\end{array}$ & $\begin{array}{c}\text { Multiparous No. } \\
\text { (Percentage) }\end{array}$ \\
\hline \multirow{2}{*}{ Ground licking } & Yes & 0 & 0 \\
\hline \multirow{2}{*}{ Sniffing } & No & $6(100)$ & $6(100)$ \\
\hline & Yes & $5(83.3)$ & $6(100)$ \\
\hline Nudging & No & $1(16.7)$ & 0 \\
\hline Yes & $6(100)$ & $6(100)$ \\
\hline Butting & No & 0 & 0 \\
\hline Maternal rejection & Yes & $6(100)$ & $6(100)$ \\
\hline Expulsion of placenta & Yo & 0 & 0 \\
\hline Posture of cow during & No & 0 & 0 \\
\hline expulsion of placenta & After 6 hours & $6(100)$ & $6(100)$ \\
\hline Licking of placenta & Sitting & $4(66.7)$ & $6(100)$ \\
\hline Planding & $2(33.3)$ & 0 \\
\hline & Yes & $3(50)$ & $4(66.7)$ \\
\hline & No & $2(30)$ & $2(33.3)$ \\
\hline & Yes & $4(66.7)$ & $1(16.7)$ \\
\hline & No & $6(100)$ & $5(83.3)$ \\
\hline
\end{tabular}


Butting was defined as pressure applied by cow to calf with head. The onset of butting up to 12 hour post-partum was $91.27 \pm 5.60$ and $70.78 \pm 10.52 \mathrm{~min}$. in primiparous and multiparous cows respectively and number of butting up to 12 hour post-partum was $6.33 \pm 0.67$ and $8.67 \pm 0.71$ times in primiparous and multiparous cows respectively (Table 1). In present study all the animals primiparous and multiparous were showing butting behavior (Table 2).

Selman et al., (1970) stated that the cows experienced or multiparous are taken care of their calf better. That was also confirmed in presented study as evidenced by early onset of sniffing, nudging and butting behavior.

The mean feeding $(122.33 \pm 4.94$ vs.109.83 $\pm 6.78 \mathrm{~min}$.$) , rumination (70.17 \pm 3.35$ vs. $58.50 \pm 4.81 \mathrm{~min}$.) and drinking $(4.87 \pm 0.40$ vs. $4.89 \pm 0.46 \mathrm{~min}$.) time up to 12 hour postpartum were summarized in table 1 . The result is non-significant in feeding, rumination and drinking time although feeding time and rumination time were higher in primiparous cows, Kunowska and Rozanska (2009) reported that it might be due to multiparous cows spent their most of the time in giving care to their calf.

In present study the urination frequency consist of total number of urination by cows during the 12 hours post-partum. The mean urination frequency up to 12 hour post-partum was $2.33 \pm 0.21$ and $2.50 \pm 0.22$ times in primiparous and multiparous cows respectively (Table 1). In present research the defecation frequency consist of total number of defecation by cows during the 12 hours post-partum. The mean defecation frequency up to 12 hour post-partum was $3.00 \pm 0.26$ and $3.17 \pm 0.31$ times in primiparous and multiparous cows respectively. Maternal rejection was occasionally seen in dairy animals in absence of licking, sniffing, nudging attempts by cows to her calf during 12 hour post-partum. As per table 2 no case of maternal rejection was noticed in both the groups during this study.

Out of six primiparous cows4 (66.7\%) expelled placenta within 6 hour post-partum and rest $2(33.3 \%)$ expelled placenta after 6 hour post-partum. However, all the multiparous cows expelled placenta within 6 hour post-partum period (Table 2).

After expulsion of placenta $2(33.3 \%)$ out of six primiparous cows were licking the placental membrane without eating it and rest $4(66.7 \%)$ out of six primiparous cows were not licking the placental membrane without eating it. After expulsion of placenta 1 $(16.7 \%)$ out of six multiparous cows were licking the placenta membrane without eating it and $5(83.3 \%)$ of multiparous cows were not licking the placental membrane (Table 2).

In present study, none of the primiparous and multiparous cows were observed with the behavior of placentophagia (Table 2).

In conclusion, it must be stated that the observed multiparous Gir cows have higher and well-developed maternal instinct as compared to primiparous Gir cows. Multiparous Gir cows showed higher intensity of grooming and licking to their calves as compared to primiparous Gir cows. Butting time and nudging time was higher in multiparous as compared to primiparous Gir cows.

\section{Acknowledgement}

I would be please to mention the names of Mr. Nayanbhai (Managing Director), Dr. Gelani and other supporting staff members of Bhestan farm, Surat for the invaluable cooperation rendered directly or indirectly during my research work. 


\section{References}

Anonymous, 2012. 19 ${ }^{\text {th }}$ Livestock Census-All India Report, Government of India Department of Animal Husbandry, Dairying and Fisheries, Ministry of Agriculture.

Ansari R. A. 2011. Studies on certain behavioural patterns in deoni breed of cattle under loose housing system (Unpublished Doctoral dissertation). NDRI, Karnal, Haryana, INDIA.

Edwards, S., and Broom, D. 1982. Behavioural interactions of dairy cows with their newborn calves and the effect of parity. Animal Behavior. 30(2): 525535.

Edwards S.A. 1983. The behavior of dairycows and their newborn calves in individual or group housing. Applied Animal Ethology.10(3): 191-198.

Hoffman, P. C., and Funk, D. A. 1992. Applied Dynamics of Dairy Replacement Growth and Management1. J of Dairy Sci.75(9): 2504-2516.

Kunowska-Slosarz, M., and Rozanska, J. 2009. High yielding cows and their calves' behaviour in the perinatal period. Roczniki Naukowe Polskiego Towarzystwa Zootechnicznego.5(2): 191-199.

Metz, J. and Metz, J. H. M. 1986. Maternal influence on defecation and urination in the newborn calf. Applied Animal Behavior Sci. 16(4): 325-333.

Selman, I. E., McEwan, A. D. and Fisher, E. W. 1970. Studies on natural suckling in cattle during the first eight hours post partum I. Behavioural studies (dams). Animal behaviour. 18: 276-283.

Szarek, J., Adamczyk, K. and Wołkowski, T. 2004. Optimization of milk and breeding use of highly productive cows. In Materials of the Conference "Problems in reproduction of cattle today and tomorrow", Polanica Zdroj. pp. 28-33.

Val- Laillet, D., Simon, M. and Nowak, R. 2004. A full belly and colostrum: two major determinants of filial love. Developmental Psychobiology.45(3): 163-173.

Huzzey, J. M., Von Keyserlingk, M. A. G., and Weary, D. M. 2005. Changes in feeding, drinking, and standing behavior of dairy cows during the transition period. J of Dairy Sci. 88(7): 24542461.

Pahl, C., Hartung, E., Grothmann, A., Mahlkow-Nerge, K. and Haeussermann, A. 2014. Rumination activity of dairy cows in the 24 hours before and after calving. $J$ of dairy sci.97(11): 69356941.

\section{How to cite this article:}

Vora, R.V., N.B. Patel, T.K.S. Rao, R.N. Gelani and Goswami, M.M. 2018. Post Parturient Behavioural Profiles in Primiparous and Multiparous Gir Cows. Int.J.Curr.Microbiol.App.Sci. 7(12): 2878-2883. doi: https://doi.org/10.20546/ijcmas.2018.712.327 